\title{
Air Pollutant Effects on the Environment of the Al-Hashimyeh Town
}

\author{
Bassam A. Al-Helou
}

\begin{abstract}
This study embarks on monitoring the air pollution affecting $\mathrm{Al}-\mathrm{Hashimyeh}$ town in Zarqa governorate by sulfur dioxide $\left(\mathrm{SO}_{2}\right)$ and hydrogen sulfide $\left(\mathrm{H}_{2} \mathrm{~S}\right)$ compared to the limits of the surrounding air as defined by Jordanian standards. Two sites in the area have been chosen with a view to making appropriate commendations to improve the air quality there on the one hand, and to considering both the environmental and economic aspects in the course of enduring socio-economic development on the other. The two selected sites have experienced a level of $\mathrm{H}_{2} \mathrm{~S}$ that exceeds the limits allowed by Jordanian standards, whereas no excess found in $\mathrm{SO}_{2}$ there. The study submits a set of recommendations to achieve this goal; they include the construction of a sulfur elimination unit from the heavy fuel at the Jordanian Petroleum Refinery, the substitution of the heavy fuel, which contains high content sulfur, at Al Hussein Thermal Power Plant by natural gas which is environmentally clean compared to heavy fuel, and for the installation of $\mathrm{SO}_{2}$ elimination units emanating from smokestacks.
\end{abstract}

Index Terms-Air pollution, concentration, sulfur dioxide, hydrogen sulfide, Jordanian standards, wind speed, wind direction.

\section{INTRODUCTION}

Al-Hashimyeh area is located north of Zarqa city, $35 \mathrm{~km}$ northeast of Amman. It is bounded by Longitude $36^{\circ} 04^{\prime}$ to $39^{\circ} 09^{\prime}$ east and Latitude $32^{\circ} 04^{\prime}$ to $32^{\circ} 10^{\prime}$ north. This town is the most polluted city in Jordan, as in [1], [2]. There are three main sources that contribute, in varying degrees, to air pollution and the emission of foul-smelling in Al-Hashimyeh town. These are: Jordanian Petroleum Refinery (JPR), Al Hussein Thermal Power Plant (HTPP), and Samra Wastewater Treatment Station (SWTS). Air pollutants of these sources emanate from the processes of fuel combustion, oil refining and the treatment of domestic waste water. In addition, road transport evokes dust and fuel combustion of different transport means contribute, too, to the pollution of the ambient air, as in [3]-[6].

On its part, the JPR produces air pollutants through its processes of fuel combustion and oil refining, especially the emitted sulfur dioxide, nitrogen oxides, carbon monoxide, sulfide hydrogen besides black carbon, whereas HTPP generates air pollutants from fuel combustion used for generating electrical power, such as sulfur dioxide, nitrogen oxides, carbon monoxide and smut. Noteworthy is the fact that the fuel used in the combustion processes contains a high

Manuscript received March 2, 2012; revised May 2, 2012. This work was supported by the Deanship of Research and Graduate Studies in Zarqa University, Jordan

Bassam Al-Helou is with the Mechanical Engineering Department, University of Zarqa, Zarqa, Jordan (e-mail: heloub@hotmail.com). proportion of sulfur, and, thus, augments the emission of $\mathrm{SO}_{2}$.

It is well-known that exposure for long to pollutants or dust causes health damages. However, health disadvantages would be much greater if man is simultaneously exposed to higher levels of more than one pollutant, namely $\mathrm{SO}_{2}, \mathrm{H}_{2} \mathrm{~S}$ and dust. Health damage especially affects children, elders and people stricken by allergy, chest diseases, asthma, as in [7]-[11]. In this study, the level of gas pollutants is checked for each of $\mathrm{SO}_{2}$ and $\mathrm{H}_{2} \mathrm{~S}$.

$\mathrm{SO}_{2}$ is a poisonous gas. It agitates the tissues of eyes, noses, pharynxes and lungs. So once absorbed by a human body, $\mathrm{SO}_{2}$ operates as an internal toxin that would possibly impair the nervous and respiratory systems. $\mathrm{SO}_{2}$ is a colorless gas, and so can not be visible when it infiltrates. Neither can it be seen in a stormy weather. It moves as an invisible cloud, usually in the wind direction. It is a heavier gas than air and tends to fall on low lands, such as ditches, drainages and holes, where it goes well as a fatal gas. The degree of $\mathrm{SO}_{2}$ effect depends on its concentration in air, as well as on the victim's allergy and exposure duration. So if $\mathrm{SO}_{2}$ condensation in air amounts to $100 \mathrm{ppm}$, it then develops eye and throat inflammation, headache, nausea, cough and the olfaction becomes useless within 3-15 minutes, as in [12]-[16]. The degree of $\mathrm{SO}_{2}$ condensation in air is based on the quantity of fuel consumption and the ratio of sulfur in there.

$\mathrm{H}_{2} \mathrm{~S}$ is another poisonous gas that is dealt with in this study. $\mathrm{H}_{2} \mathrm{~S}$ is a colorless gas with a powerful smell produced by combustion. In its chemical composition, it contains sulfur. The $\mathrm{H}_{2} \mathrm{~S}$ gas dashes into air from oil refineries, factories and electricity generating stations which all use coal or oil. Hence oil plants are among the most significant sources of this pollutant, in addition to power stations, industrial activities and the vehicles which use fuel with high sulfur rate. $\mathrm{H}_{2} \mathrm{~S}$ inflames eye tissues and the respiratory system. It is rather harmful with its rate exceeding 3ppm in air, as in [17]-[19]. $\mathrm{H}_{2} \mathrm{~S}$ is also considered a component of acidic rain which pollutes soil, plants, rivers, lakes and water sources, thus causes environmental imbalance and damage to buildings, as in [20].

These two pollutants have been checked in this study within the limits determined by the Jordanian standards of the ambient air (table I) in the two chosen sites: Ibn El Anbari and Um Shuraik Schools in Al-Hashimyeh town.

\section{AIR MONITORING SiteS}

Al-Hashimyeh air quality monitoring sites consist of two stations; Ibn El-Anbary School (IES) which is located about $6 \mathrm{~km}$ south west SWTS, $0.5 \mathrm{~km}$ north HTPP and $1.5 \mathrm{~km}$ east 
JPR, and Um Shuraik School (USS) which is located about 3 km west south SWTS, $2 \mathrm{~km}$ north HTPP and $2 \mathrm{~km}$ north east JPR, as in [5]. "Fig.1" indicates the geographical locations of the monitoring sites and the three sources pollution.

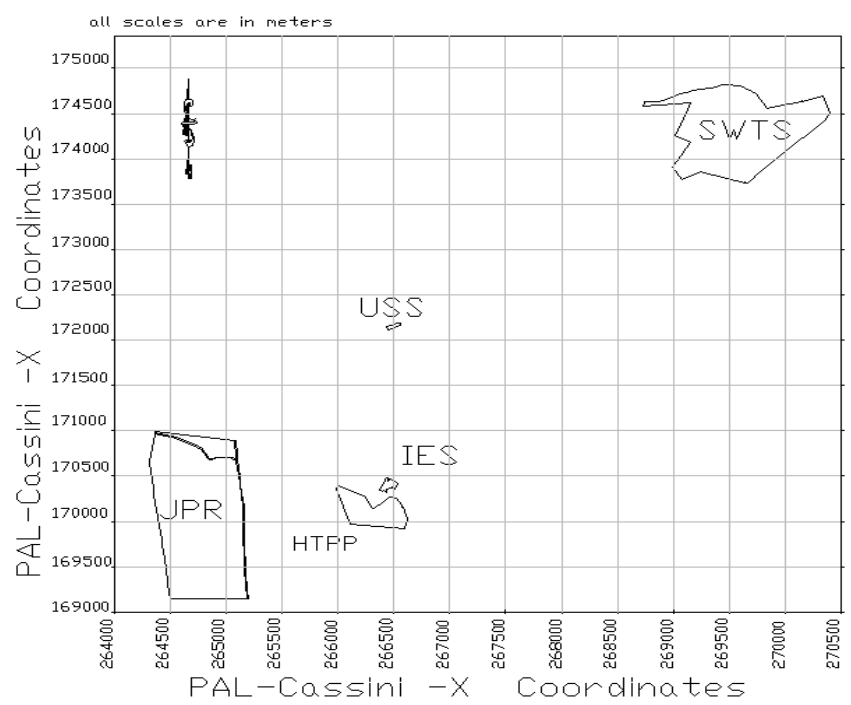

Fig. 1. The geographical locations of the monitoring sites and the three sources pollution.

\section{Monitoring Procedures}

$\mathrm{SO}_{2}$ and $\mathrm{H}_{2} \mathrm{~S}$ analyses are done using Ultra-Violet Fluorescence. The analysis equipment is calibrated by a Portable Calibration model that involves Permeation tubes. The Wind speed and direction are measured at both sites by a Metro-Unit. Additionally, meteorological data are collected at the Zarqa town weather station. Wind speed, wind direction, ambient temperature, barometric pressure, and solar radiation are measured hourly. The meteorological data are being collected to permit correlation of pollutants levels and wind characteristics, and to develop a database for future dispersion modeling application.

TABLE I: $\mathrm{SO}_{2}$ AND $\mathrm{H}_{2} \mathrm{~S}$ POLLUTANTS CONCENTRATION LIMITS IN JORDAN STANDARD 1140/2006, [21].

\begin{tabular}{llll}
\hline \hline Pollutant & $\begin{array}{l}\text { Average } \\
\text { Exposure Time }\end{array}$ & $\begin{array}{l}\text { Concentration } \\
\text { Limit }(\mathrm{ppm})\end{array}$ & $\begin{array}{l}\text { Number of Allowed } \\
\text { Exceedances }\end{array}$ \\
\hline $\mathrm{SO}_{2}$ & 1 hour & 0.3 & $\begin{array}{l}\text { Three times within } \\
\text { any } 12 \text { months }\end{array}$ \\
\hline $\mathrm{SO}_{2}$ & 24 hours & 0.14 & $\begin{array}{l}\text { One time within a } \\
\text { year }\end{array}$ \\
\hline $\mathrm{SO}_{2}$ & Annual & 0.04 & - \\
\hline $\mathrm{H}_{2} \mathrm{~S}$ & 1 hour & 0.03 & $\begin{array}{l}\text { Three times within } \\
\text { any 12 months }\end{array}$ \\
\hline $\mathrm{H}_{2} \mathrm{~S}$ & 24 hours & 0.01 & $\begin{array}{l}\text { Three times within } \\
\text { any 12 months }\end{array}$ \\
\hline \hline
\end{tabular}

\section{RESUlTS AND Discussion}

\section{A. Hydrogen Sulfide $\mathrm{H}_{2} \mathrm{~S}$}

SWTS and JPR are the two main sources which pollute the ambient air by $\mathrm{H}_{2} \mathrm{~S}$ in Al-Hashimyeh area. The emanating $\mathrm{H}_{2} \mathrm{~S}$ from SWTS exposes the IES atmosphere to pollution as the highly swift north-eastern wind blows, or when winds repose for a long period of time. IES location lies relatively afar from the SWTS, precisely to its south-west, and not of a far distance from the east of JPR during the blowing or quietude of the western and north-western winds.

The USS location is a closer point of observation of SWTS. It lies to the west and south-west of SWTS. So USS shall be exposed to pollution by $\mathrm{H}_{2} \mathrm{~S}$ of SWTS when winds are calm and as eastern and north-eastern winds blow. It shall also be affected by $\mathrm{H}_{2} \mathrm{~S}$ of JPR when south-western winds blow.

"Fig.2" and "Fig.3" show that the daily averages and the maximum hourly average of $\mathrm{H}_{2} \mathrm{~S}$ concentrations. The maximum hourly was $0.259 \mathrm{ppm}$ at IES and $0.206 \mathrm{ppm}$ at USS, and that the hourly's average has exceed the Jordanian standard No $1140 / 2006$ of 0.03 ppm by 33 times (i.e. $0.38 \%$ ) at IES and by 202 times (i.e. $2.3 \%$ ) at USS.

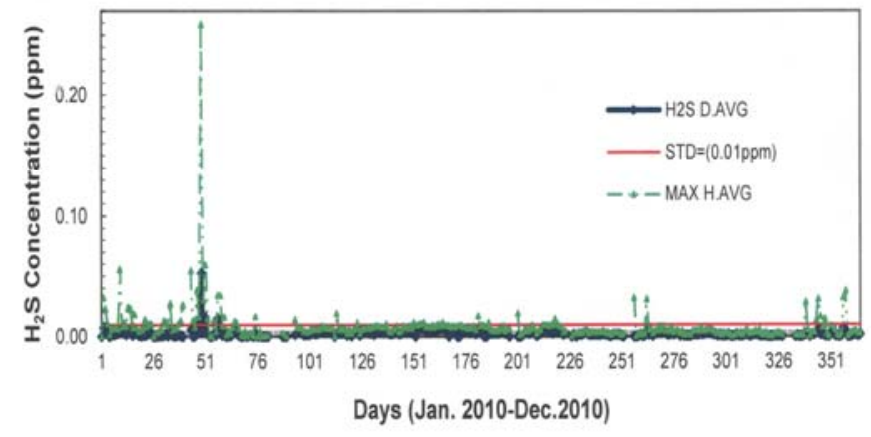

Fig. 2. Daily averages and maximum hourly averages of $\mathrm{H}_{2} \mathrm{~S}$ concentrations at IES.

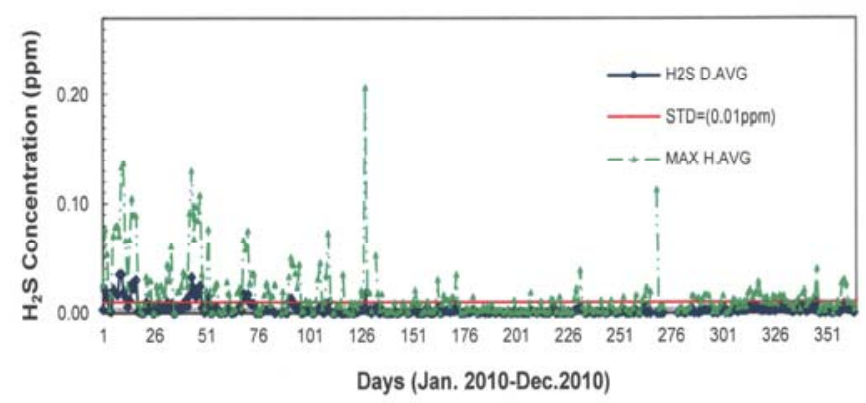

Fig. 3. Daily averages and maximum hourly averages of $\mathrm{H}_{2} \mathrm{~S}$ concentrations at USS.

The results of monitoring $\mathrm{H}_{2} \mathrm{~S}$ during the period of this study (Jan-Dec 2010) demonstrate that USS site was exposed to the highest degrees of $\mathrm{H}_{2} \mathrm{~S}$ gas. That is due to its proximity to SWTS, and to the high rate of calm winds during the period when excesses of the limits of the daily Jordanian standards were recorded and amounted to $67.8 \%$ "Fig.4". The results also show that the IES site continues to be exposed to medium levels of this gas, thanks to the calm winds that prevailed clearly during the days of recording those excesses and reached $68.4 \%$, followed by the western winds at a rate of $28.9 \%$ "Fig. 5 ", which are capable to carry $\mathrm{H}_{2} \mathrm{~S}$ from the JPR to IES. 


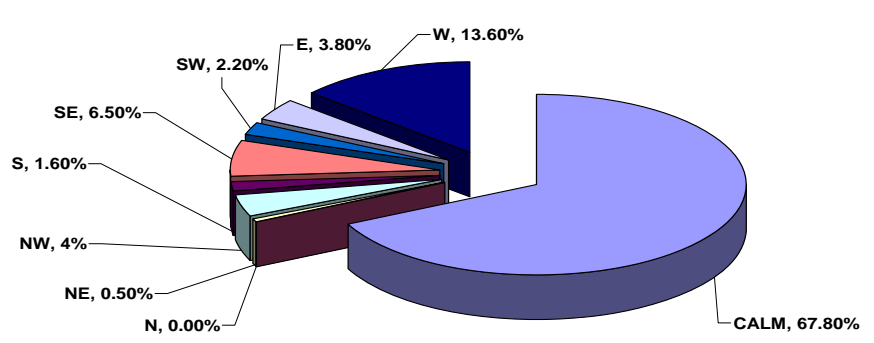

Fig. 4. Wind direction distribution during days on which $\mathrm{H} 2 \mathrm{~S}$ daily average concentration exceeded JS Daily at USS.

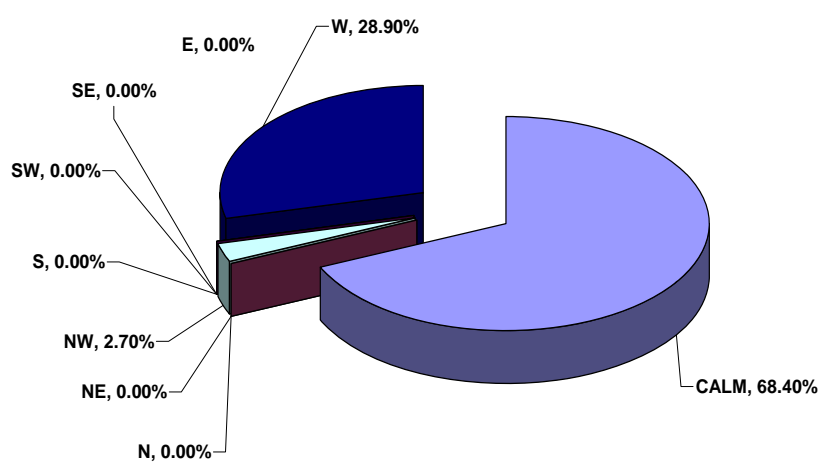

Fig. 5. Wind direction distribution during days on which $\mathrm{H}_{2} \mathrm{~S}$ daily average concentration exceeded JS Daily at IES.

Table II also displays the maximum daily averages and the number of daily excesses at both sites of monitoring. It shows the rise in the daily average excesses to the standard limits at USS compared to those at the IES. The maximum daily average at IES was $0.053 \mathrm{ppm}$, and excesses were 3 times and amounted to $0.82 \%$, whereas the maximum daily average at USS was $0.035 \mathrm{ppm}$, and excesses were 27 times with $7.39 \%$.

TABLE II: The MAXimum DAILy AVERAgeS AND THE Number OF DAILY EXCESSES AT BOTH SITES.

\begin{tabular}{lccc}
\hline \hline Site & $\begin{array}{c}\text { Max. Daily Averages } \\
\text { ppm }\end{array}$ & $\begin{array}{c}\text { Number of Daily } \\
\text { Excesses }\end{array}$ & $\begin{array}{c}\text { Daily } \\
\text { Excesses \% }\end{array}$ \\
\hline IES & 0.053 & 3 & 0.82 \\
USS & 0.035 & 27 & 7.39 \\
\hline \hline
\end{tabular}

The study has found out that the maximum monthly average reached $0.006 \mathrm{ppm}$ at IES in February and $0.011 \mathrm{ppm}$ at USS in January (see Table III). It has also noted that calm winds prevailed in February by $66.9 \%$ and western winds by $20.9 \%$, the latter being capable of carrying $\mathrm{H} 2 \mathrm{~S}$ from the JPR to the monitoring site at the IES. Meanwhile, calm winds were prevalent in January by $43.2 \%$ and north and north-eastern winds predominated during the same month by $11.6 \%$. These winds can carry the emanating gas from SWTS to USS "Fig.6" and "Fig.7". This underlines the important role played by calm winds in carrying $\mathrm{H}_{2} \mathrm{~S}$ from SWTS to USS monitoring site and the JPR contribution to the recorded excesses at the IES.
TABLE III: MONTHLY AVERAGES OF $\mathrm{H}_{2} \mathrm{~S}$ CONCENTRATIONS AT BOTH SITES.

\begin{tabular}{lllllll}
\hline \hline Site & Jun & Feb & Mar & April & May & Jun \\
\hline IES & 0.002 & 0.006 & 0.001 & 0.003 & 0.004 & 0.005 \\
USS & 0.011 & 0.008 & 0.004 & 0.004 & 0.002 & 0.002 \\
\hline \hline & & & & & & \\
\hline \hline July & Aug & Sept & Oct & Nov & Dec & Y.avg \\
\hline 0.004 & 0.003 & 0.002 & 0.002 & 0.001 & 0.002 & 0.003 \\
0.001 & 0.001 & 0.004 & 0.002 & 0.003 & 0.003 & 0.004 \\
\hline \hline
\end{tabular}

It was in the early morning hours when the highest $\mathrm{H}_{2} \mathrm{~S}$ levels were recorded at the USS. Apparently, the record was done before sunshine had revived the winds movement which usually stays calm for eight hours at night "Fig. 8 ". It is also noted that the annual and seasonal averages of $\mathrm{H} 2 \mathrm{~S}$ concentration in each hour of the day at the USS were proportionally inverse with the wind's speed "Fig.8"and "Fig.9", taking into account the closer proximity of the site to the main source of air pollution by $\mathrm{H}_{2} \mathrm{~S}$. Moreover that, the highest rates of $\mathrm{H}_{2} \mathrm{~S}$ at the USS site were recorded during the winter, which is distinct of its low wind speed compared to other seasons. It should, however, be mentioned here that wind stability plays a different role in carrying gas emissions emanating from land level sources from those coming from smokestacks. That is when wind stabilizes at night, it helps the SWTS- $\mathrm{H}_{2} \mathrm{~S}$ gas reach the nearby areas, such as the USS, with higher concentration rate. "Fig10" shows that the highest concentration rates of $\mathrm{H}_{2} \mathrm{~S}$ were found recorded at sunshine up to $1: 00 \mathrm{pm}$ at the IES which is close to JPR, and when wind speed was increasingly faster.

Correlation analysis is a tool that measures the relationship between two data sets. The population correlation calculation returns the covariance of two data sets that are divided by the product of their standard deviations. The Correlation tool can be also used to determine whether the two ranges of data move together. That is, whether the large values of one set are associated with those of the other (positive correlation); whether small values of one set are associated with large values of the other (negative correlation), or whether values in both sets are unrelated (correlation near zero), as in [22]. The correlation analysis of $\mathrm{H}_{2} \mathrm{~S}$ concentrations "Fig.11" does not indicate a clear link between the concentrations at the two sites.

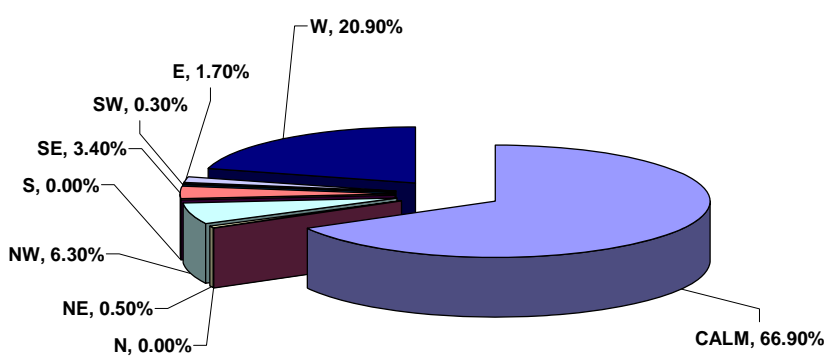

Fig. 6. Monthly wind direction distribution in Feb. 2010. 


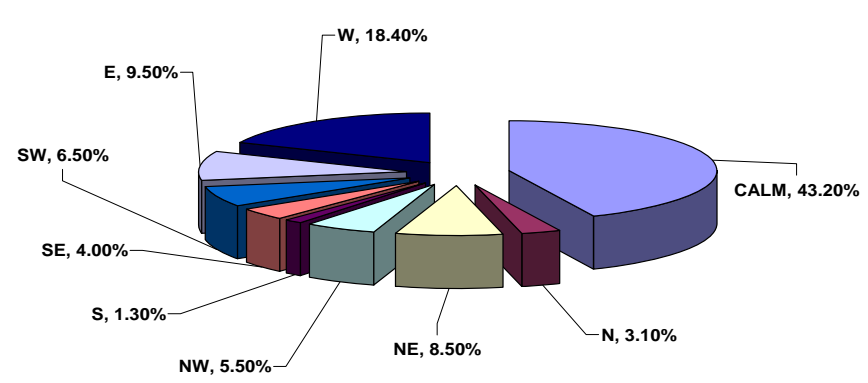

Fig. 7. Monthly wind direction distribution in Jan. 2010.

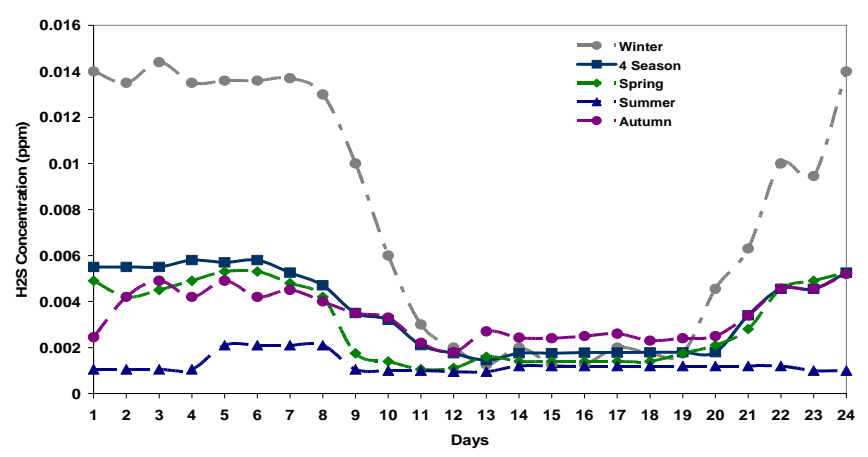

Fig. 8. Average diurnal concentration of $\mathrm{H}_{2} \mathrm{~S}$ at USS (Jan. 2010 -Dec. 2010).

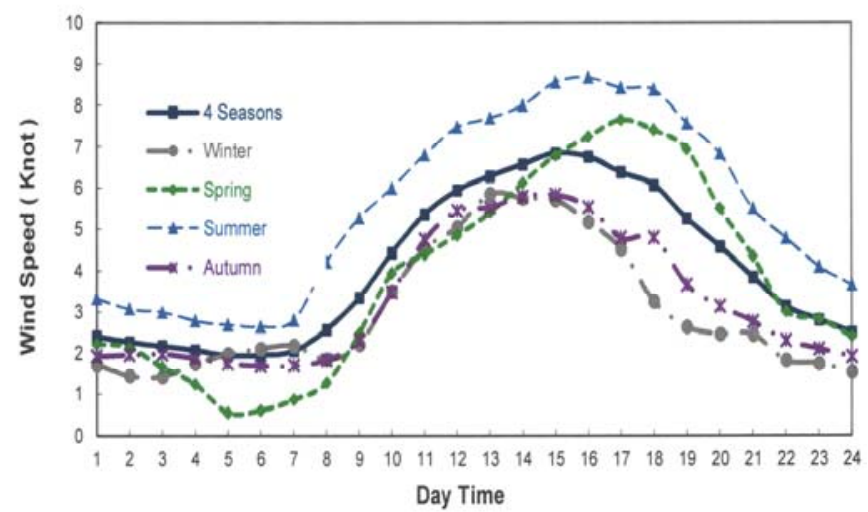

Fig. 9. Wind speed diurnal averages (knot) at Al-Hashimyeh (Jan. 2010-Dec. 2010).

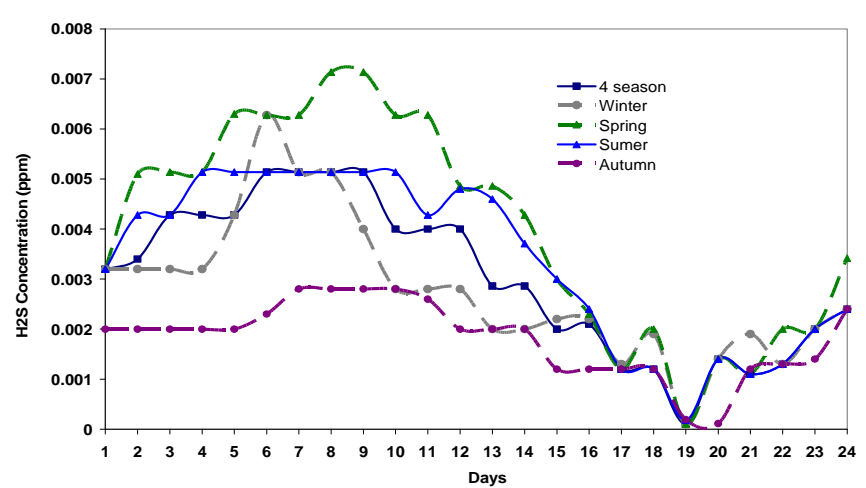

Fig. 10. Average diurnal concentration of $\mathrm{H}_{2} \mathrm{~S}$ at IES (Jan. 2010-Dec. 2010).

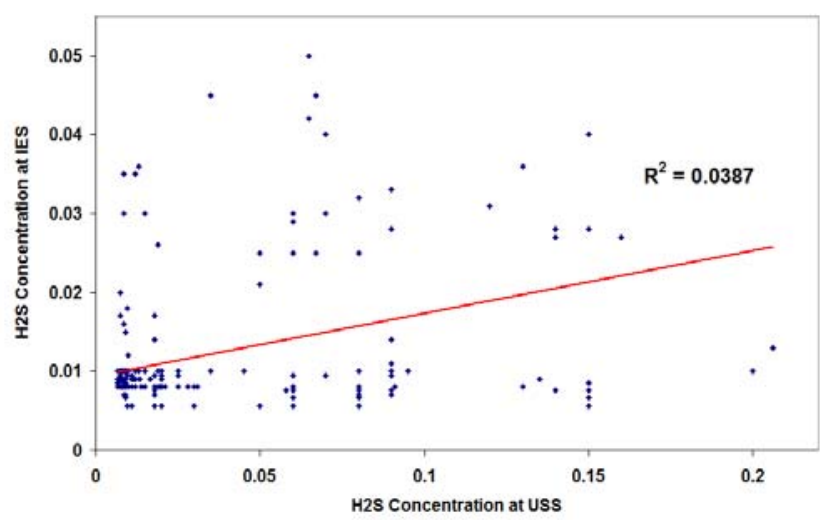

Fig. 11. Correlation analysis of daily average $\mathrm{H}_{2} \mathrm{~S}$ Concentration.

\section{B. Sulfur Dioxide $\mathrm{SO}_{2}$}

The HTPP and JPR are the two main consistent sources of the $\mathrm{SO}_{2}$ emission in Al-Hashimyeh town. $\mathrm{SO}_{2}$ emission is the result of the fuel combustion and refinement that contains high rate of sulfur. Indeed, the IES site is affected by $\mathrm{SO}_{2}$ emanating from the JPR by the wind blowing from the west and north-west, whereas western winds carry it to the same site as blowing from the HTPP.

Figures 12 and 13 show that the daily average and the maximum hourly concentration of monitoring $\mathrm{SO}_{2}$, the maximum hourly concentration were $0.226 \mathrm{ppm}$ and $0.204 \mathrm{ppm}$ at the IES and USS respectively. This means that no excess to the limit of the Jordanian standard of $0.3 \mathrm{ppm}$.

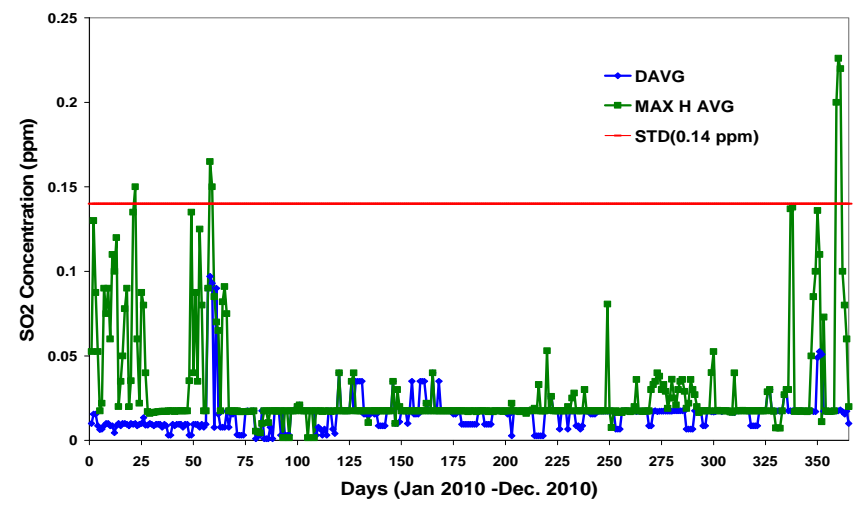

Fig. 12. Daily averages and maximum hourly averages of $\mathrm{SO}_{2}$ concentrations at IES.

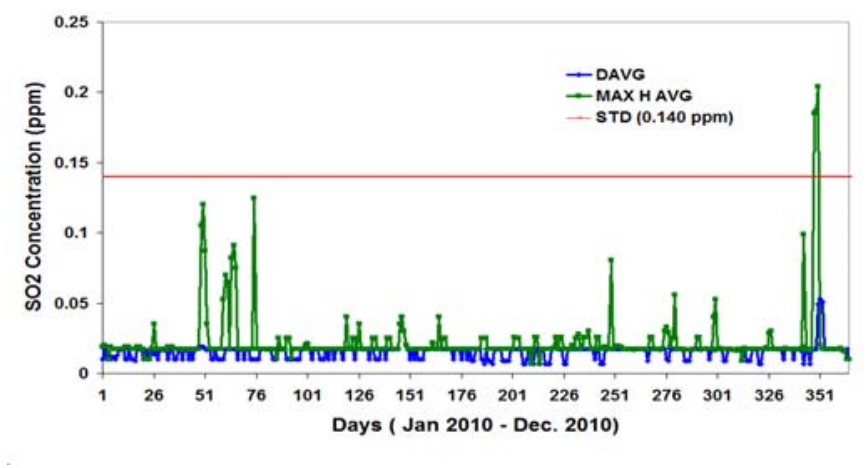

Fig. 13. Daily averages and maximum hourly averages of $\mathrm{SO}_{2}$ concentrations at USS. 
TABLE IV: MONTHLY AVERAGES OF $\mathrm{SO}_{2}$ CONCENTRATIONS.

\begin{tabular}{lllllll}
\hline \hline Site & Jun & Feb & Mar & April & May & Jun \\
\hline IES & 0.011 & 0.013 & 0.004 & 0.004 & 0.005 & 0.005 \\
USS & 0.002 & 0.004 & 0.003 & 0.002 & 0.002 & 0.001 \\
\hline \hline & & & & & & \\
\hline \hline July & Aug & Sept & Oct & Nov & Dec & Y.avg \\
\hline 0.005 & 0.004 & 0.004 & 0.005 & 0.003 & 0.007 & 0.006 \\
0.001 & 0.001 & 0.003 & 0.002 & 0.002 & 0.004 & 0.002 \\
\hline \hline
\end{tabular}

Both figures also show that the daily average at IES was $0.097 \mathrm{ppm}$ and $0.053 \mathrm{ppm}$ at the USS. It can be noted that daily averages were low at both sites, and no excesses occurred to the $0.14 \mathrm{ppm}$ of the Jordanian standard.

Table IV points to the monthly average of $\mathrm{SO}_{2}$. No resemblance was noted in the type of change of $\mathrm{SO}_{2}$ monthly average at both sites regarding rise or drop. The highest level recorded at the IES during February was $0.013 \mathrm{ppm}$, whereas it was $0.004 \mathrm{ppm}$ at USS during December and February. Hence it can be stated that the monthly averages were low in both sites.

The above Table also shows the annual average of $\mathrm{SO}_{2}$ at both sites of IES and USS. It was $0.006 \mathrm{ppm}$ and 0.002 at the IES and USS respectively. Besides, no excess to Jordanian standard has been noted, and that annual averages were also at both sites.

Monitoring $\mathrm{SO}_{2}$ shows that USS was less affected by that gas pollution. USS actually lies at a distance from $\mathrm{SO}_{2}$ sources. So no excess occurred and the monitoring account recorded at the USS was lower than that at the IES, no matter that no excess to the Jordanian standards in the latter was recorded. That is due to the direction of the winds that prevailed during the period of this study. Indeed, the USS can only be affected by $\mathrm{SO}_{2}$ from HTPP if south winds prevail. Those winds were $0.5 \%$ during the period of the study. On the other hand, USS was affected only by the south western winds blowing from the JPR. These winds didn't exceed $8.0 \%$. So the monitoring account remained low during the period of this study "Fig.14".

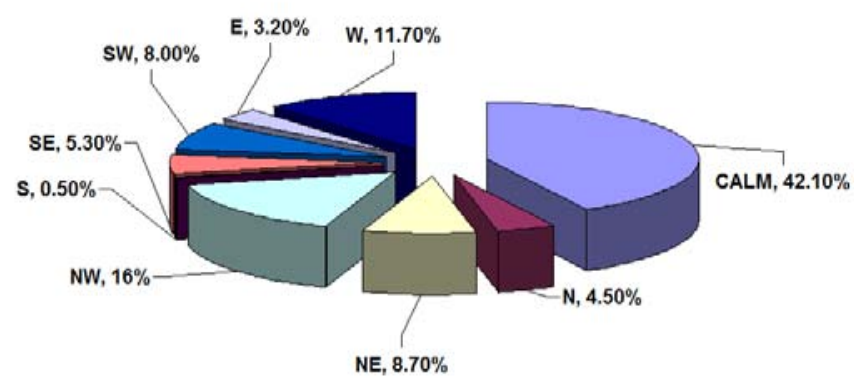

Fig. 14. Wind direction distribution at Al-Hashimyeh (Jan. 2010 - Dec. 2010).

\section{CONCLUSION}

1. The calm winds prevail in Al-Hashimyeh town in most of the night hours. Thus, the pollutants emanating from the source accumulate in a form of a cloud whose space and content grow as the wind calms sustains.
2. The wind speed begins by sunrise. It usually blows from the west, carrying with it the night-accumulated pollution, towards Al-Hashimyeh town in the east of HTPP and JPR.

3. The study recommends the substitution of heavy fuel, which contains high rate of sulfur and is used in HTPP, by natural gas which is environmentally clean, the building of a sulfur elimination unit from heavy fuel, or the installation of $\mathrm{SO}_{2}$ elimination units that would clean the smokestack emissions of the JPR and HTPP.

4. Both the JPR and HTPP are urged to employ more efficient and environment-friendly technology on their premises.

5. Building expansion in the east and south-east HTPP is not advised as air quality in these areas could be affected, though these areas are distant from the pollution sources, especially because of the prevailing weather conditions there, namely air quietness.

6. It has been pointed out by this study that calm winds play a significant role in carrying $\mathrm{H}_{2} \mathrm{~S}$ from SWTS to the USS, and that the JPR contribute to the recorded excesses in IES.

7. The study has shown that $\mathrm{H}_{2} \mathrm{~S}$ exceeded the Jordanian standard in both sites, whereas no surpassing was recorded by $\mathrm{SO}_{2}$.

8. The highest rates of $\mathrm{H}_{2} \mathrm{~S}$ in the USS were recorded at times of wind quietude, whereas that occurred in IES at rising wind speed.

9. The highest rates of $\mathrm{H}_{2} \mathrm{~S}$ at the USS site were recorded during the winter, which is distinct of its low wind speed compared to other seasons.

\section{ACKNOWLEDGMENT}

The author would like to thank Jordanian Ministry of Environment for providing the air quality data necessary for this study, and Deanship of Research and Graduate Studies in Zarqa University -Jordan for the financial support in conducting this study.

\section{REFERENCES}

[1] S. Odat, "Diurnal and Seasonal Variation of Air Pollution at Al-Hashimeya Town" Jordan Journal of Earth and Environmental Sciences, vol. 2, no. 1, pp 1-6, 2009.

[2] Directorate of Environment in Al- Zarqa. Reports About Al-Hashimeya Area, 2000.

[3] Jordan Petroleum Refinery Company (JPRC). Annual Report. Amman, Jordan, 2006.

[4] Al- Hussein Thermal Plant. Report for Air Quality Monitoring for the Selected Site of Assamra Power Project at Al- Hashimeya, 2001.

[5] Ministry of Environment. Annual Report, 2010.

[6] Study the levels of pollutants in the area of Al-Hashimeya. Ministry of Environment. Annual Report, 2004.

[7] A. Seaton, W. MacNee, K. Donaldson, and D. Godden, " Particulate Air Pollution and Acute Health Effects”, The Lancet. vol. 345, pp. 176-178, 1995. 
[8] A. Peters, H. Wichmann, T. Tuch, J. Heinrich, and J. Heyder, " Respiratory Effects are Associated with the Number of Ultra-fine Particles", American Journal of Respiratory Critical Care Medicine, vol. 155, no. 4, pp. 1376-83, April 1997.

[9] D.T Mage, and O. Zali, "Motor Vehicle Air Pollution: Public Health Impact and Control Measures," WHO/PEP/92.4, World Health Organization and ECOTOX, Switzerland, 1992

[10] World Health Organization, (2006). "WHO Air quality guidelines for particulate matter, ozone, nitrogen dioxide and sulfur dioxide". Global update 2005. Summary of risk assessment. World Health Organization Available:

http://www.who.int/phe/health topics/outdoorair aqg/en/index.html.

[11] APPA, "La pollution de 1'air: sources, effets, prévention, Association pour la Prévention de la Pollution Atmosphérique," Ville de Besançon Service Hygiene Santé, France 1998.

[12] D. Burki, and J. Keller, GaBE/Air pollution. Part 2: Concentrations of major air pollutants in Switzerland and trans boundary contributions, Paul Scherrer Institute, Switzerland, pp. 5280-5290, 1994.

[13] A. Jol and G. Kielland, "EEA Air Pollution in Europe", European Environment Agency, Copenhagen. pp. 51-58, 1997.

[14] [14] S. Fally, D. Joannes, D. Leduc, and M Scharll,. "La pollution, ses effets et ses coûts en région de Bruxelles-capitale", Université Libre de Bruxelles, Belgique. 1995.

[15] A. Lefohn, and D. Shadwick, "Ozone, sulfur dioxide and nitrogen dioxide trends at rural sites located in the United States', Atmospheric Environment, vol. 25A, no. 2, pp. 491-501, 1998.

[16] P. Kalabokas, L. Viras, C. Repapis, and J Bartzis, "Analysis of the 11-year record 1987-1997 of air pollution measurements in Athens," Greece. Part II: Photochemical air pollutants', Global Nest: the International Journal, vol. 1, pp. 169-176, 1999.

[17] EPA, "Report to Congress on Hydrogen Sulfide Air Emissions Associated with the Extraction of Oil and Natural Gas." EPA-453/R-93-045, pp. III-4, October 1993.
[18] Public Health Statement for Hydrogen Sulfide. Agency for Toxic Substances and Disease, September 2004. Available: http://www.atsdr.cdc.gov/toxprofiles/tp114-c1.pdf.

[19] New York State Department of Health: available at http://www.health.state.ny.us/nysdoh/environ/btsa/sulfide.htm.

[20] [20] F. Menz, and H. Seip, "Acid rain in Europe and the United States" An Update. Environ. Sci. Policy, 7, 253, 2004.

[21] Jordanian Standards, Standard Number 1140, for 2006.

[22] B. Al-Helou and B. Sinokrot, "Air Quality Comparison between Industrial and Residential Communities," Environment \& Ecology, vol. 22, no.3, pp. 586-591. 2004.

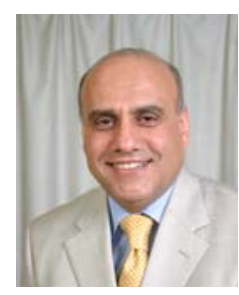

Bassam A. Al-Helou received his $\mathrm{PhD}$ degree in Mechanical Engineering from Budapest Technical University in Hungary in 1992 . He has published more than 17 papers in referred national and international journals. He has also presented several articles in national and international conferences.

$\mathrm{He}$ is now Associate Professor of Mechanical Engineering in Electrical Engineering Department at Zarqa University in Jordan. He was Dean of Faculty of Engineering, Director, Center for Consultation, Continuing Education, and Community Service, Head of Electrical Engineering Department, Chairman of Engineering Workshops. He has more than 20 years of teaching and research experience.

He is a member of ASHRAE, American Society of Mechanical Engineers, Jordan Engineering Association. 